\title{
Dispute Resolution of Islamic Financial Institutions, Court Litigation and Negotiation
}

\author{
Shamsalden Aziz Salh \\ Soran University, Faculty of Law, Political Science and Management, \\ Law Department \\ Shamsalden.salh@soran.edu.iq
}

\begin{abstract}
Dispute resolution in the Islamic financial sector is one of the current debates among regulators and Sharia scholars. When Islamic financial institutions have a dispute with their customers, have to search for a solution. The first step for the Islamic financial institutions for resolving the dispute is to start negotiation with their clients. Islamic financial institution negotiates with the client through Shariah supervisory committee members. Sharia scholars of the committee are experts in Shariah law. These Shariah members have an excellent reputation and well-known in society. Hence, the negotiation starts with the client resolving the dispute in order to not go to court. The advantages of the negotiation are taking less cost and less time and it is confidential which is very important for the Islamic financial institution. However, the decision that is reached by negotiation maybe not binding on the parties which consider a disadvantage of the negotiation method. If the parties could not resolve the dispute by negotiation, then the case will go to court. Most of the courts either based on the civil or common law system. Therefore, the decision made by these courts maybe not the right decision as the judges decide on the Shariah case according to civil or common law. Despite the court process take long time and is costly, but the decision that is made by the court is binding on the institution and the client. Some countries decide on Islamic financial legal cases in Shariah courts, such as the Kingdom of Bahrain. In a country like the UK, the decision on the Islamic financial cases will be under the English law system. Therefore, the Bahraini approach is an ideal solution, and the Malaysian approach is one of the best solutions, as the court refers to Shariah Advisory Council when the case is about Islamic finance. Purpose of This Paper: This paper purposes to observe the dispute resolution of Islamic financial legal cases and find solutions for the disputes between the Islamic financial institutions and their customer according to the current legal system in the world. Research Method: This research applies a qualitative descriptive method and analysis legal cases related to Islamic finance. the researcher describes the dispute resolution of Islamic financial institutions and then analyses the result of the research. The data collection for this research is from primary and secondary sources. Thus, court cases, books, journals, and related websites are the main source for data collection for this study. Findings: It is found that the current legal court system in many countries is not proper for resolving issues that arise between Islamic financial institutions and their clients. Thus, dispute resolution in the Islamic financial industry needs to be resolved by negotiation and mediation between the Islamic financial institutions and their customers. Furthermore, the courts have crucial rules in resolving these issues. However, lack of the Shariah courts in many countries in the world makes civil or common law courts decide on the issues, which judges are appointed on these courts do not have Shariah background.
\end{abstract}

Keywords: Dispute resolution, Civil law court, Common law court, Negotiation, and Court litigation.

DOI: $10.7176 / \mathrm{IAGS} / 90-04$

Publication date: March $31^{\text {st }} 2021$

\section{1- Introduction}

Conventional financial institutions do not have a problem with the current judicial system. The judicial system is based on civil or common law; hence it is a proper system for the conventional financial system. However, the current judicial system in many countries in the world is problematic for Islamic financial institutions. The Islamic financial industry is based on the Shariah legal system which takes all its rules and regulations from a religion of Islam. Therefore, the effect of the judicial system will appear when there is a dispute between an Islamic financial institution and the client. Occurring disputes between Islamic financial institutions and their client need to be settled before affecting the reputation of the institution. Due to the reason that Islamic banking and finance growth rapidly, the disputes increase between the Islamic banking and financial institutions and their customer. Therefore, there should be a method for resolving the issue that slows down Islamic financial 
institutions' development. There is alternative dispute resolution for any Islamic financial case before the case is sent to the court. Generally, Islamic banks attempt to find solutions for their disputes and avoiding to go to court. The first method for the Islamic banking and financial institutions is negotiation. The financial institution attempts to settle the issue with its client through negotiation. For the negotiation, members of the Shariah board have an important role. As these members are respectable and have a good reputation in the society. ${ }^{1}$ However, if the issue could not be settled by negotiation, the second stage will start which is going to the court. It is in favor of both the Islamic finance institution and the client that the case settled down by negotiation.

\section{2- Islamic Financial System}

The role of Islamic financial institutions cannot be denied in developing an economic system in the world. ${ }^{2}$ As conventional financial institutions, Islamic financial institutions have a vital role in supporting and improving the financial sector in general. Recently, the number of Islamic financial institutions has increased very fast in the world, not only in Muslim countries but also in non-Muslim countries, such as the United Kingdom, for example, Islamic Bank of Britain. ${ }^{3}$ The number of investors who invest their funds with Islamic financial institutions has increased. Due to religious reasons, Muslims deal with Islamic financial institutions rather than conventional financial institutions. Thus, Islamic financial institutions have their important role in developing the economy. The system of the Islamic financial industry is different from the conventional system, as the first one is based on Shariah law. Thus, the Islamic financial system is regulated by Shariah law and supervised by a special committee to ensure the Shariah law is not breached. ${ }^{4}$ The most important principle of the Islamic financial system is profit-and-loss sharing (PLS), where customers are part of the financial institution. Thus, customers share the profit and loss with the Islamic financial institution according to an agreement between these two parties. Another principle of Islamic finance is the prohibition of interest ( $r i b a$ ). Islamic financial institutions are not allowed to deal with interest, which is against Sharia law. Receiving and paying interest leads to the termination of the transactions.

Therefore, in a dispute situation in Islamic finance cases, the Shariah law is the first to be looked at, as the Shariah principles are applied to this type of finance. In this context, the nature of disputes in the Islamic financial system is different from the nature of disputes in the conventional financial system. In that case, the dispute resolution of the Islamic financial system should be special and should be under Shariah law. It is preferred for resolving Islamic financial institution issue to refer to Shariah court if exist. However, in many countries, the Shariah court does not exist. As a result, Islamic financial legal cases going through the civil or common law court system.

\section{3- The Judiciary and The Court System}

Today the court system in the world is mostly based on civil or common law according to the country's legal system. Most countries follow either common law or civil law in the world. For instance, in UK and Malaysia, the legal system is based on common law or English Law, ${ }^{5}$ while the legal system in a country like France is based on civil law. ${ }^{6}$ The common law system is uncodified while civil law is codified. As it is stated that:

Common law is generally uncodified. This means that there is no comprehensive compilation of legal rules and statutes. While common law does rely on some scattered statutes, which are legislative decisions, it is largely based on precedent, meaning the judicial decisions that have already been made in similar cases. These precedents are maintained over time through the records of the courts as well as historically documented in collections of case law known as yearbooks and reports. The precedents to be applied in the decision of each new case are

\footnotetext{
${ }^{1}$ Azhar Abdul Rahman and Abdullah Awadh Bukair, 'The Influence of the Shariah Supervision Board on Corporate Social Responsibility Disclosure by Islamic Banks of Gulf Co-Operation Council Countries' (2013) 6, Asian Journal of Business and Accounting. 77.

${ }^{2}$ Nalan IŞIK, Growth, 'Islamic Banking and Schumpeterian Vision: An Empırıcal Evidence from the Gulf Arab States' (2018) 4 International Journal of Islamic Economics and Finance Studies 45.

${ }^{3}$ Abdul Karim Aldohni, 'The Emergence of Islamic Banking in the UK: A Comparative Study with Muslim Countries' (2008) 22 Arab Law Quarterly 181.

${ }^{4}$ Middle East and North Africa, 'Arbitrating Islamic Banking and Finance Disputes: A Proposal for Semi-Secular Arbitration' Dr. Gordon Blanke < https://mena.thomsonreuters.com/en/resources/articles/arbitrating-islamic-banking-and-financedisputes.html> accessed 3 March 2021.

${ }^{5}$ Tun Abdul Hamid Mohamad and Adnan Trakic, 'The reception of English law in Malaysia and development of the Malaysian common law' (2015) 44 Common Law World Review 124.

${ }^{6}$ THE WORLD FACTBOOK, France Legal system $<$ https://www.cia.gov/the-world-factbook/field/legal-system $>$ accessed 8 March 2021.
} 
determined by the presiding judge. As a result, judges have an enormous role in shaping American and British law. ${ }^{7}$

It is noted that common law is a case law in which judges made decisions on a legal case according to the previous cases that have similar nature to that recorded before. Thus, the common law court does not rely on one comprehensive compilation of legal rules and acts. Hence, common law or case law is an unwritten law which different from civil law.

Nevertheless, civil law is a codified law as it is stated that:

Civil Law is codified. Countries with civil law systems have comprehensive, continuously updated legal codes that specify all matters capable of being brought before a court, the applicable procedure, and the appropriate punishment for each offense. Such codes distinguish between different categories of law: substantive law establishes which acts are subject to criminal or civil prosecution, procedural law establishes how to determine whether a particular action constitutes a criminal act, and penal law establishes the appropriate penalty. In a civil law system, the judge's role is to establish the facts of the case and to apply the provisions of the applicable code. Though the judge often brings the formal charges, investigates the matter, and decides on the case, he or she works within a framework established by a comprehensive, codified set of laws. The judge's decision is consequently less crucial in shaping civil law than the decisions of legislators and legal scholars who draft and interpret the codes. ${ }^{8}$

In contrast to common law, civil law is a codified law that consists of acts and statutes that are applicable for amendment according to the county's situation and time. In the civil court, judges in the court decide on any legal case according to the current laws and rules that apply to that case. Furthermore, civil law is written law in the shape of Acts and regulations.

Looking at the civil and common law systems are based on man-made law which is different from Sharia law. Therefore, the judges in civil and common law systems are experts in these two systems. Most probably judges are not experts in Shariah legal system as they have a civil or common law background. Thus, the Sharia case issues cannot be decided by either civil or common courts. In this sense, legal cases of Islamic financial institutions cannot be brought to non-Islamic courts.

\section{4- Islamic Financial Legal Cases and Dispute Resolution}

Dispute resolution in Islamic financial institution's cases can go into two stages. The first stage is going through mediation and negotiation which is preferred to resolve their disputes through negotiation. The second stage is court litigation, in which the legal case going to court to be resolved.

\section{4-1- Mediation and Negotiation}

When there is a dispute relating to Islamic financial institutions, the first thing that comes to mind is alternative dispute resolution. Alternative dispute resolution in Islamic finance is negotiation and mediation which is run by Shariah scholars of Islamic financial institutions. It is preferred for the Sharia supervisory board of any Islamic financial institution to consist of three to seven ${ }^{9}$ Shariah scholars who are experts in Sharia-related issues. When there is a dispute between the institution and its clients the member of the Shariah committee starts to move by the institution to resolve the case by negotiation. In that context, the Sharia supervisory committee of the Islamic financial institution can have an important role as part of alternative dispute resolution. It is preferred for any financial institution to appoint and select Sharia scholars who reputable and famous among the public for its Shariah supervisory committee. Besides, Sharia scholars should be qualified in their field to have the ability to supervise Islamic financial transactions and contracts. ${ }^{10}$ The role of Sharia supervisory committee members did not finish here, hence, they have a significant role in dispute resolution in Islamic banking legal cases. In a

\footnotetext{
7 C Law, 'THE COMMON LAW AND CIVIL LAW TRADITIONS' https://www.law.berkeley.edu/wpcontent/uploads/2017/11/CommonLawCivilLawTraditions.pdf accessed 1 March 2021.

8 C Law, 'THE COMMON LAW AND CIVIL LAW TRADITIONS' https://www.law.berkeley.edu/wpcontent/uploads/2017/11/CommonLawCivilLawTraditions.pdf accessed 1 March 2021.

${ }^{9}$ Azhar Abdul Rahman and Abdullah Awadh Bukair, 'The Influence of the Shariah Supervision Board on Corporate Social Responsibility Disclosure by Islamic Banks of Gulf Co-Operation Council Countries' (2013) 6, Asian Journal of Business and Accounting. 76.

${ }^{10}$ Iskandar Muda, 'The Effect of Supervisory Board Cross-Membership and Supervisory Board Members' Expertise to the Disclosure of Supervisory Board's Report: Empirical Evidence from Indonesia' (2017) 20 European Research Studies Journal 595.
} 
country like Malaysia, the negotiation is regulated by law. Thus, Section 56 of the Central Bank Act 2009 of Malaysia provides two mechanisms for settlement of disputes in Islamic banking which are litigation and arbitration. $^{11}$

Generally, Islamic financial institutions require Shariah supervisory members to enter into a negotiation with the customer who has a problem with the Islamic financial institution. The negotiation method could include arbitration, mediation, and any amicable method. In the mediation and arbitration method, a third party has it is placed in the negotiation. However, the Shariah Supervisory committee members are the main characters in the negotiation process. Thus, Sharia members attempt to resolve the issue before going to court. The negotiation should be by mutual consent between parties. Hence, if one of the parties does not agree to resolve the case through the negotiation, the case with go for the court proceeding.

The advantage of the negotiation between the Islamic financial institution and the client is to reduce the cost and save time. The cost of the negotiation is a small amount which may be given to the mediator if there is any. Besides, the case will be settled as quickly as possible. ${ }^{12}$ In addition, confidentiality is another advantage for Islamic financial institutions when they settle the case by negotiation. Privacy is very important for financial institutions as confidentiality is their priority. However, someone may ask if there is a mediator, then the confidentiality is at risk. The researcher believes that the mediator is someone who is selected by the Islamic financial institution. Thus, the mediator should be trusted as the parties selected him in mutual agreement. Therefore, the institution attempts to settle the dispute with their customers through negotiation rather than going to court.

\section{4-2- Court Litigation}

If the issue between the Islamic financial institution and the client could not be settled via negotiation through Sharia supervisory committee members and the mediator, the case will go to a court. The court takes a case and both the Islamic financial institution and the client as two parties waiting for the decision of the court. As aforementioned that many countries' courts are based on either civil or common law systems. Thus, judges in these courts are professional in their field, common law and civil law other than Shariah law. Therefore, it is difficult for the Islamic financial institution and the client to obtain their rights, as the judges are not experts in Sharia legal system. When there is a dispute between an Islamic financial institution and a customer, the court is an exact place after failing to settle the issue via negotiation. The issue starts here in the court if the judges are not professional in Islamic jurisprudence and Shariah rules. ${ }^{13}$

Some countries that have Shariah courts for settling Islamic financial legal cases resolve the problem in this court. For instance, in the Kingdom of Bahrain Shariah court deal with all Shariah-related issues including Islamic finance cases. Thus, in Bahrain Shariah courts cover all the issues of the personal status of Muslims. It implies the Islamic finance judiciary is organized with Sharia courts since it refers to Islamic law. ${ }^{14}$

In some other countries like Malaysia, even the common law courts decide on issues relating to Islamic finance but the Judges request advice from the Sharia Advisory council which is Central Sharia Committee in Malaysia. As stated in the Central Bank Act 2009:

Where in any proceedings relating to Islamic financial business before any court or arbitrator any question arises concerning a Shariah matter, the court or the arbitrator, as the case may be, shall- (a) take into consideration any published rulings of the Shariah Advisory Council; or (b) refer such question to the Shariah Advisory Council for its ruling. ${ }^{15}$

On the other hand, those countries that do not have Shariah court and all cases related to Sharia issues of Islamic financial institutions are settled under the civil or common law court such as in the UK. The UK legal system is

\footnotetext{
${ }^{11}$ N. Khalidah Dahlan, 'Alternative Dispute Resolution for Islamic Finance in Malaysia' (2018) 150, MATEC Web of Conferences $<\quad$ https://www.matecconferences.org/articles/matecconf/abs/2018/09/matecconf_mucet2018 05077/matecconf_mucet2018_05077.html> accessed 3 March 2021.

12 Jonathan Lawrence, 'Peter Morton and Hussain Khan, Dispute Resolution in Islamic Finance' Global Islamic Finance Report 2012,

${ }^{13}$ NUR KHALIDAH DAHLAN MOHD. RIZAL PALIL, 'The Challenges of Alternative Dispute Resolution for Islamic Finance in Malaysia' (2018) 20, JUUM 15.

${ }^{14}$ Nuha Qonita, 'THE EMERGENCE OF LEGAL SYSTEM IN ISLAMIC FINANCE' Jurisdictie: Jurnal Hukum dan Syariah $9(2018) 75$.

${ }^{15}$ Malaysia Central Bank Act 2009, Section 56.
} 
based on English law and the courts in this country are followed by case law. Therefore, any Islamic financial legal case will be treated under common law courts.

In the renowned English case of Beximco Pharmaceuticals Ltd v Shamil Bank of Bahrain EC 2 [2004] EWCA Civ 19, one of the issues concerned the governing law of the contract. The contract stated that "subject to the principles of Glorious Sharia'a, this agreement shall be governed by and construed in accordance with the laws of England". At trial, the judge, when dealing with the question of the applicable law, referred to the Rome Convention on the Law Applicable to Contractual Obligations 1980 and stated that the convention only made provision for the choice of law of a country, and did not provide for the choice of law of a nonnational system of law, such as Sharia law. It was held that a contract can only have one governing law and that parties to a contract can only agree to adopt the law of a country as the governing law of a contract. Therefore, according to English law, as Sharia law is a nonnational system of law it is not capable of being the governing law of a contract. ${ }^{16}$

In the case of Beximco Pharmaceuticals Ltd v Shamil Bank of Bahrain ${ }^{17}$ can be seen that judges decided according to the English law, not Sharia law as it is not capable of being the governing law of contract. Besides, the judge stated that Shariah law is not the country's law. ${ }^{18}$ Therefore, the decision cannot be made according to Shariah law. Judges in common law courts do not have knowledge of Islamic Sharia law and they do not make a decision according to the Shariah law. In that context, the decision may be not proper for Islamic financial institutions. Therefore, Islamic financial institutions attempt to settle their issue and dispute with their client through negotiation and mediation rather than settled through the court. ${ }^{19}$

There are some disadvantages to settling legal cases through court. Firstly, high cost, when the disputes are resolved by courts institutions, the institution needs to spend an amount of money until the court makes a decision. Similarly, the client needs to spend money when they go to court to settle the dispute with an Islamic financial institution. Therefore, settling legal cases by courts is costly more than settling them by negotiation. Secondly, time-consuming, taking a legal case by courts takes a long time until is settled. The Islamic financial institution and the client need to resolve their as soon as possible because the long time take the case need more cost. The third disadvantage of settling a legal case between the Islamic financial institution and the client is nonconfidentiality. Islamic financial institutions in general keep the privacy of the institution and the client. However, when a case holds by the court to be settled between the Islamic financial institution and its client, then confidentiality will be under threat. In this case, Islamic financial institution avoids settling the dispute by the courts that are to keep the privacy of the institution. Besides all these issues, the civil or common law judges may not give the right decision about Shariah legal cases of Islamic financial institutions as these judges to a certain extent do not have Shariah Law knowledge. ${ }^{20}$ Therefore, settling disputes by negotiation is preferred by Islamic financial institutions. However, when the legal disputes are settled by the court it is considered binding on both parties, the Islamic financial institution, and the client. On the other hand, the negotiation's decision maybe not binding on the parties because it does not come out from the court unless if there is a pre-agreement between parties states that the decision is binding on both parties.

\section{5- Conclusion}

Today Islamic financial institutions suffer from a lack of Sharia courts in many countries which affects the industry negatively. Legal cases of Islamic financial institutions directly go to the civil or common law courts due to the lack of Shariah courts. Therefore, the decisions that made by these courts do not satisfy the Islamic financial institutions. In this context, Islamic financial institutions attempt to resolve their issues with their client through negotiation and mediation before the case goes to court. Thus, the negotiation is considered as arbitration as Shariah members of the financial institution's committees' role as a negotiator is highly appreciated. However, if the dispute could not be settled by negotiation or mediation, the court should have its role in the

\footnotetext{
${ }^{16}$ Jonathan Lawrence, 'Peter Morton and Hussain Khan, Dispute Resolution in Islamic Finance' Global Islamic Finance Report 2012,

${ }^{17}$ Court of Appeal, Civil Division 28 January 2004 [2004] EWCA Civ 19.

${ }^{18}$ Nicholas H D Foster, 'Encounters between legal systems: recent cases concerning Islamic commercial law in secular courts' (2006) 68 Amicus Curiae 2.

${ }^{19}$ NUR KHALIDAH DAHLAN MOHD. 'RIZAL PALIL, The Challenges of Alternative Dispute Resolution for Islamic Finance in Malaysia' (2018) 20, JUUM 15.

${ }^{20}$ Zulkifli Hasan and Mehmet Asutay, 'AN ANALYSIS OF THE COURTS' DECISIONS ON ISLAMIC FINANCE DISPUTE (2011) 3SISRA International Journal of Islamic Finance 50.
} 
settlement of the case. Islamic financial institutions attempt to settle the dispute quickly as they need to spend less time and less cost. Hence, if the case is settled by courts then the Islamic financial institutions and the client need to spend a long time and a big amount of money. However, the court decision is binding on the conflict parties while the negotiation decision may not be binding on the parties. In some countries, Islamic financial cases go to Sharia court, while in some countries these cases are settled by the civil or common court. The lack of Sharia experts in these courts is considered a serious issue of Islamic financial institutions.

\section{References}

- $\quad$ Malaysia Central Bank Act 2009.

- $\quad$ Court of Appeal, Civil Division 28 January 2004 [2004] EWCA Civ 19.

- Abdul Karim Aldohni, 'The Emergence of Islamic Banking in the UK: A Comparative Study with Muslim Countries' (2008) 22 Arab Law Quarterly 181.

- Azhar Abdul Rahman and Abdullah Awadh Bukair, 'The Influence of the Shariah Supervision Board on Corporate Social Responsibility Disclosure by Islamic Banks of Gulf Co-Operation Council Countries' (2013) 6, Asian Journal of Business and Accounting. 76.

- C Law, 'THE COMMON LAW AND CIVIL LAW TRADITIONS', https:/www.law.berkeley.edu/wp-content/uploads/2017/11/CommonLawCivilLawTraditions.pdf accessed 1 March 2021.

- Iskandar Muda, 'The Effect of Supervisory Board Cross-Membership and Supervisory Board Members' Expertise to the Disclosure of Supervisory Board's Report: Empirical Evidence from Indonesia' (2017) 20 European Research Studies Journal 595.

- Jonathan Lawrence, Peter Morton and Hussain Khan, 'Dispute Resolution in Islamic Finance' Global Islamic Finance Report 2012,

- Middle East and North Africa, 'Arbitrating Islamic Banking and Finance Disputes: A Proposal for Semi-Secular Arbitration' Dr. Gordon Blanke https://mena.thomsonreuters.com/en/resources/articles/arbitrating-islamic-banking-and-financedisputes.html> accessed 3 March 2021.

- N. Khalidah Dahlan, 'Alternative Dispute Resolution for Islamic Finance in Malaysia' (2018) 150, MATEC Web of Conferences $<$ https://www.matecconferences.org/articles/matecconf/abs/2018/09/matecconf_mucet2018_05077/matecconf_mucet2018_ 05077.html> accessed 3 March 2021.

- Nalan IŞIK, 'Growth, Islamic Banking and Schumpeterian Vision: An Empırıcal Evidence from the Gulf Arab States' (2018) 4 International Journal of Islamic Economics and Finance Studies 45.

- Nicholas H D Foster, 'Encounters between legal systems: recent cases concerning Islamic commercial law in secular courts’ (2006) 68 Amicus Curiae 2.

- Nuha Qonita, 'THE EMERGENCE OF LEGAL SYSTEM IN ISLAMIC FINANCE' (2018) 9 Jurisdictie: Jurnal Hukum dan Syariah 75.

- NUR KHALIDAH DAHLAN MOHD. RIZAL PALIL, 'The Challenges of Alternative Dispute Resolution for Islamic Finance in Malaysia’ (2018) 20, JUUM 15.

- THE WORLD FACTBOOK, France Legal system $<$ https://www.cia.gov/the-worldfactbook/field/legal-system> accessed 8 March 2021.

- Tun Abdul Hamid Mohamad and Adnan Trakic, 'The reception of English law in Malaysia and development of the Malaysian common law' (2015) 44 Common Law World Review 124.

- Zulkifli Hasan and Mehmet Asutay, 'AN ANALYSIS OF THE COURTS' DECISIONS ON ISLAMIC FINANCE DISPUTE’ SISRA International Journal of Islamic Finance 3 ( 2011) 50. 